\title{
INNOVATION OF THE PROCESS MANAGEMENT COST SYSTEM. ARE THE ABC AND THE BALANCED SCORECARD METHODS SUFFICIENT FOR THE COST MANAGEMENT?
}

\author{
[Inovace systému procesního rrízení nákladů. Jsou metody ABC a Balanced \\ Scorecard pro ř́zení nákladů dostatečné?]
}

\author{
Michal Mitáček ${ }^{1}$ \\ ${ }^{1}$ Slezská univerzita, Obchodně podnikatelská fakulta, Univerzitní nám. 1934/3,733 40 Karviná \\ Email:o102203@opf.slu.cz
}

\begin{abstract}
The aim of this article is to describe the cost process management using the $\mathrm{ABC}-$ Activity-Based Costing method. Based on the case study the implementation of the $\mathrm{ABC}$ method into an already used strategic management Balanced Scorecard method in the production company not only the implemented methods results, but also the critical implementation gaps and the methods for a complex costs management are shown. In the following part the addition of other possible managerial methods is designed that will lead to more precise cost management, as well as to monitoring and avoiding risks associated with the costs amount in connection with the company performance management. The ultimate goal of this article is to draft a new complex management system for the cost management and business performance. Used tools and managerial methods designed to control the cost and performance are following: Balanced Scorecard, Activity-Based Costing, Performance Management, Business Process Management, Business Continuity Management.
\end{abstract}

Keywords: Activity-Based Costing (ABC), Balanced Scorecard (BSC), Business Process Management, Cost Accounting, Cost Management, Performance Management.

JEL classification: M10

Doručeno redakci: 2.12.2015; Recenzováno: 22.12.2015; 6.1.2016; Schváleno k publikování: 23.3.2016

\section{Úvod}

Rozvoj podnikání a stále silnější konkurenční prostř̌edí s sebou přináší bezpodmínečnou nutnost kvalitnějšího řízení výkonnosti, zvyšování produktivity procesů a sofistikovanějšího řízení nákladů. To vše s důrazem na vzájemné propojení. Náklady se příliš nezabývat, spíše se věnovat velikosti tržeb a hlavně zisku, to byl trend manažerského řízení v období před počátkem celosvětové ekonomické krize. Pokud firma vykazovala rostoucí tržby, př́liš neřešila, zda jsou všechny náklady relevantní a zda neexistují ve firmě činnosti, které nepřináší žádnou přidanou hodnotu, jak pro firmu samotnou, tak i pro zákazníky. Navíc výše nepř́mých nákladů častokrát rostla vyšším tempem, než rostly tržby. Opačným extrémem řízení u některých fïrem bylo maximalistické snižování nákladů, které pak často vedlo až k zastavení růstu tržeb, nebo dokonce k jeho nekontrolovanému snižování.

Malé a střední firmy nemají dostatečné technické možnosti a zdroje pro efektivní sledování a řízení nákladů, potažmo pak vyhodnocování výkonnosti jednotlivých procesů. Manažersky vyspělejší firmy využívají svého informačního systému a různých softwarových nadstaveb ke sledování výkonnosti a samotnému řízení nákladů. Tyto zmiňované firmy, které řídí a kontrolují svoji činnost vyspělejším způsobem, používají většinou pro strategické řízení manažerský systém ř́zení výkonnosti Balanced Scorecard (BSC) a propojují jej s dalšími operativními systémy rrízení nákladů, jako je např. metoda Activity-Based Costing (ABC). Firem, využívajících těchto řídících prostředků, je však stále hodně málo. Ostatní firmy náklady a výkonnost většinou řídí jen intuitivně na základě dlouholetých zkušeností řídících pracovníků. Při takovém řízení se však může u řídících pracovníků kromě nedostatečných 
podkladů pro rozhodování (analyzovaných dat) vyskytovat i tzv. „profesní slepota“, která zamezí vyššímu stupni analýzy problému (takto se to dělá již dlouhou řadu let a není důvod to měnit) a většinou, pokud se tito manažeři vůbec pustí do nějaké změny, tak to končí sice snižováním nákladů, ale tato rozhodnutí vedou také ke snižování vlastní výkonnosti a v krajním př́ípadě mohou vést i k ohrožení samotné existence firmy (finanční ztráta, ztráta klíčových zákazníků, nevhodná modernizace technologií, plýtvání se zdroji, zhoršení Cash flow).

Problémem řešeným v příspěvku je zkvalitnění systému procesního řízení nákladů ve výrobní firmě. Na základě př́ípadové studie bude ukázáno, jakým způsobem středně velká výrobní firma zavedla, kromě již používaného systému strategického řízení BSC, systém procesního řízení nákladů pomocí metody $\mathrm{ABC}$, jaké vznikly při implementaci problémy, do jaké míry skloubení těchto dvou systémů pomohlo samotnému řízení a na základě kterých problémů a kritérií bylo doporučeno připojit další možné manažerské systémy pro zvýšení komplexnosti ř́zení.

Hlavním cílem příspěvku je ukázat skutečnou funkci implementované metody řízení nákladů $\mathrm{ABC}$ a vyhodnotit výsledky získané analýzou nákladů. Dílčími cíli jsou:

- specifikace problémů při implementaci této metody a stanovení nedostatků při jejím praktickém využití,

- navržení opatření k eliminaci nedostatků metody $\mathrm{ABC}$,

- vytvoření návrhu komplexního manažerského systému procesního řízení nákladů a výkonnosti firmy.

Struktura př́spěvku je následující:

- Úvod - možnosti a podmínky řízení nákladů ve firmách, vytýčení řešeného problému a stanovení hlavního cíle a dílčích cílů příspěvku.

- Teoretický rámec problému - shrnutí základních pojmů a teorie k metodám BSC a $\mathrm{ABC}$, doplnění o novodobé poznatky o slučitelnosti těchto dvou metod.

- Praktická implementace metody ABC ve výrobní firmě - př́ípadová studie implementace metody $\mathrm{ABC}$, alokace režijních nákladů do procesních aktivit a následně do nákladových objektů, vyhodnocení stěžejních nákladů a určení ztrátových nákladových objektů (výrobkových řad), strategický pohled na metodu $\mathrm{ABC}$.

- Problémy implementace systému ABC a nedostatky pro řízení nákladů - stanovení problémů a nedostatků po zkušebním provozu implementace.

- Návrhy na odstranění nedostatků metody ABC a řízení výkonnosti - návrhy opatření a vytvoření návrhu komplexního systému řízení nákladů a výkonnosti.

- Závěr - zhodnocení výsledků a provedených návrhů.

\section{Teoretický rámec problému}

Neustálý tlak na snižování nákladů vede u některých podniků dokonce $\mathrm{k}$ snižování produktivity, nestálému zhoršování Cash-flow a nedostatečné rentabilitě vlastního kapitálu. Jak uvádí Doyle (2006, s. 16-18), manažeři překvapivě zjišt’ují tři neočekávané skutečnosti:

- Skryté efekty: snižování nákladů může poškodit kvalitu produktu, odradit zákazníky a dodavatele, dává špatný signál jak akcionářum a bankám, tak i uvnitř střednímu managementu i zaměstnancům, kteří vnímají negativní důsledky růstu produktivity.

- Důraz na osobní náklady: mzdy jsou jako vždy v hledáčku snižování nákladů. I když představují jen zlomek celkových nákladů, zatímco fixní režie roste exponenciálně. Finanční manažeři jsou zahlceni zaznamenáváním počtu hodin př́mé práce, produktivity a analyzují malé odchylky od rozpočtu, zatímco se nevěnují materiálovým nákladům, 
které mohou přesáhnout i 50 \% nákladů, stejně tak i režijním nákladům, které mohou být i $30 \%$ a v neposlední řadě i nadbytečným zásobám.

- Selhávání kalkulačních systémů: zavádění automatizace a neustálý růst produktivity má za následek selhávání kalkulačního systému. Nové technologie vyžadují méně lidské práce a naopak se zvyšují enormně odpisy, což s sebou nese i riziko špatného výpočtu nákladů.

Doyle (2006, s. 14) proto varuje, že: „jakmile je dalši fáze snižování nákladů ve firmě dokončena, zůstává skutečná výzva v hledání modelu, který zajištuje, že zdroje jsou alokovány $v$ oblasti, kde je podnik dokáže nejlépe zhodnotit, a nejsou zaměstnávány vokrajových aktivitách a současně jsou náklady měřitelné a tedy řiditelné. Řizení nákladů jednoduše je pevně spjaté s existencí podniku a mélo by to tak $i$ zůstat."

Které metody pro řízení výkonnosti a nákladů tedy zvolit, kterými metodami začít, jakou část z nich aplikovat, jak jednotlivé metody mezi sebou propojit, jak tyto metody společně vyhodnocovat? To jsou jen některé otázky, které si každý vlastník i manažer musí zákonitě pokládat, když chce řídit prosperující společnost.

Výzkum vytvořený z podnětu amerického Institute of Management Accountants uvádí (Kaplan, 2010, s. 20), že zdaleka nejpřednějším systémem řízení výkonnosti firmy se stal systém Balanced Scorecard (BSC), který značně předstihl systémy založené na řízení jakosti, např. kritéria Baldrigerovy ceny, model excelence Evropské nadace pro ř́zení jakosti (EFQM), Six Sigma, nebo systémy finančního řízení, např. model přidané ekonomické hodnoty, EVA, atd..

Balanced Scorecard je strategický manažerský systém, který převádí poslání a strategii společnosti do cílů a měřitek zařazených do čtyř perspektiv: finanční, zákaznické, interních procesů a učení se a růstu. Čtyři perspektivy umožňují stanovit rovnováhu mezi krátkodobými a dlouhodobými cíli. Model BSC je zobrazen na obrázku 1.

Obrázek 1: model BSC

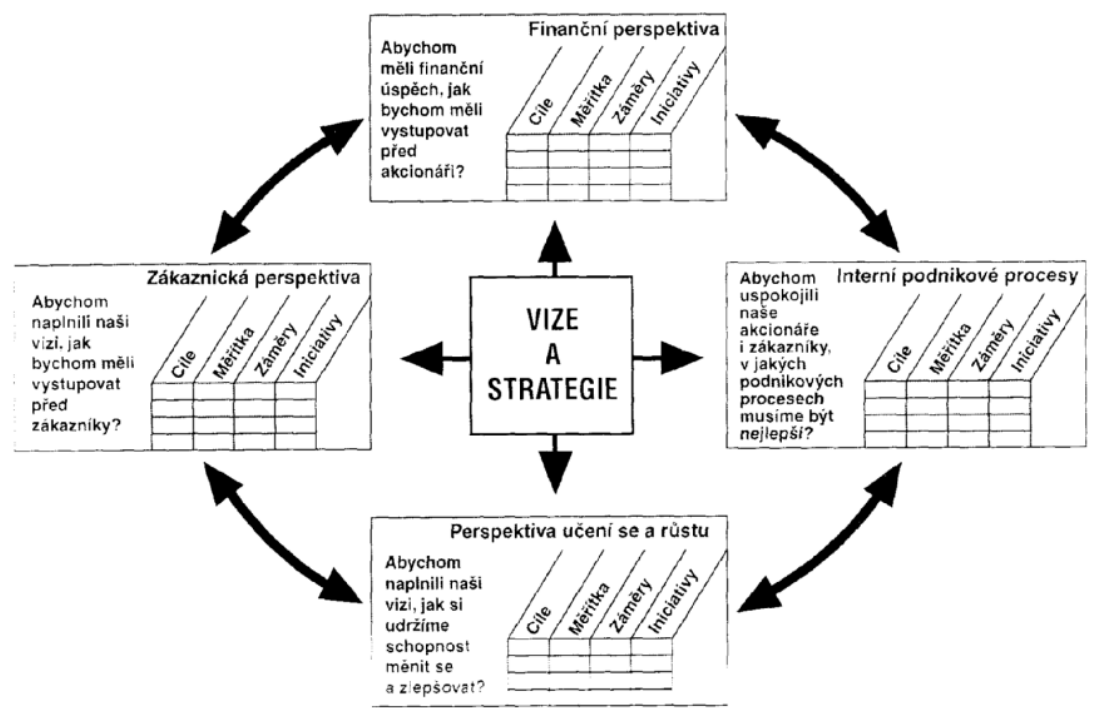

Zdroj: Kaplan (2007, s. 18-20)

K finančnímu řízení nákladů se využívá nákladové účetnictví (Cost Accounting), jež je součástí manažerského účetnictví. Král (2010, s. 21-22) definuje řízení nákladů jako: 
„systémové zobrazení podnikatelského procesu vjeho úplnosti a nepřetržitosti včetně jeho výsledkü, charakterizujícich činnost podniku v hodnoceném období. Projevuje se zdůrazněnou potřebou koordinovat dílči aktivity, činnosti a procesy a rozvíji takzvané Procesni nákladové účetnictví. "Hlouběji se finančním řízením nákladů zabývá metoda ABC. Ale ani ta nedává komplexní pohled. Kterou metodu a systém použít, jak ho spojit s jiným nástrojem, kdy který nástroj řízení použít tak, aby to bylo efektivní a nezvýšila se zbytečná administrativa?

Možné spojení moderních komplexních metod řízení a hodnocení výkonnosti firem zmiňuje Petrrík (2007, s. 123-134). Uvádí, že v podmínkách koncepce řízení nákladů pomocí metody ABC/Management, je tato metoda vnímána jako efektivní doplněk komplexních metod řízení, jako jsou např́iklad zmiňované BSC anebo Řízení podle cílů (Management by objectives MBO). Z toho je zřetelné, že jedna samostatná metoda není schopna obsáhnout tak rozsáhlou problematiku, jakou řízení nákladů spolu s řízením výkonnosti je.

Z výzkumu, který v roce 2012 provedla Asociace malých a středních podniků a živnostníků v České republice a jehož výsledky jsou uvedeny na obrázku 2, vyplývá, že v malých a středních podnicích se využivá manažerských metod $\mathrm{k}$ řízení výkonnosti a nákladů jen zhruba v $30 \%$ př́ípadů. Zbytek podniků a vlastně i manažerů tyto metody bud' vůbec nezná, nebo je ve firmě nepoužívá. $Z$ obrázku 2 lze dále vysledovat, že nejvíce využívanou metodou ve firmách využívajících manažerské metody řízení jsou metody Balanced Scorecard a Six Sigma.

Obrázek 2: Použití manažerských metod ve firmě
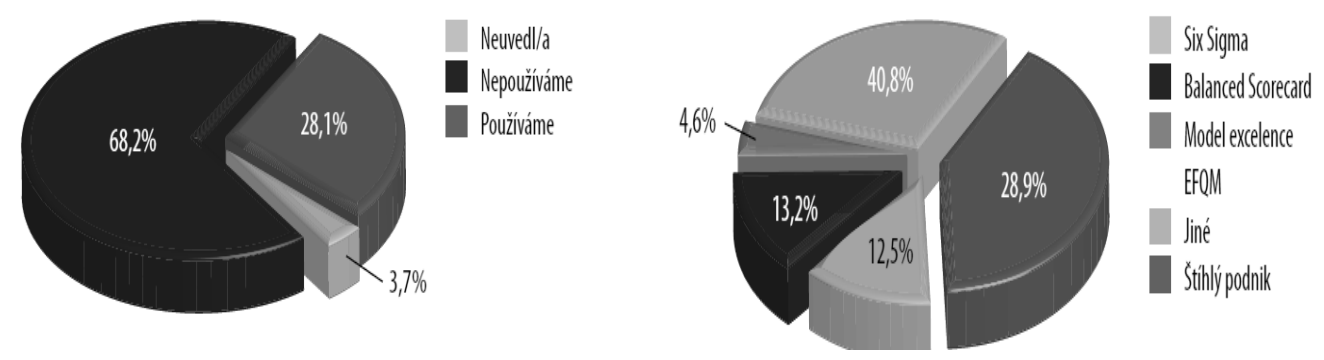

Zdroj: Webový portál AMSP: Výsledky průzkumu č. 10 AMSP ČR - Názory podnikatelů na moderní metody ř́zení společnosti [online] [vid. květen 2011]. Dostupné z: www.amsp.cz/uploads/dokumenty/ AMSP_Pruzkum_C10.pdf

Zatímco strategický systém BSC se zaměřuje na manažerské řízení výkonnosti firmy zaměřené spíše do budoucnosti, metoda $\mathrm{ABC}$, tedy řízení nákladů podle aktivit, slouží k vyhodnocování nákladovostí jednotlivých aktivit a přiřazování nákladů nákladovým objektům. Používá přitom skutečných fyzických výkonů jednotlivých prováděných činností a aktivit a odhaluje tak skutečné příčiny vzniku nákladů (Popesko 2009, s. 100).

Je to tedy systém určený $\mathrm{k}$ analýze jednotlivých nákladů a prričin vzniku. Přesto na základě těchto manažerských informací lze účelně vyspecifikovat i výkonnostní kritéria jednotlivých aktivit, jejich řízení a pomocí přiřazení skutečných nákladů $\mathrm{k}$ jednotlivým nákladovým objektům, tedy skupině výrobků. Vyhodnocením ziskovosti nákladových objektů pak lze jasně určit, které výrobky jsou pro firmu stěžejní, ziskové a kterých se naopak firma musí postupně zbavit. A tímto pak vlastně přechází celý systém $\mathrm{z}$ operativního řízení a vyhodnocování controllingu do strategické roviny, kdy se rozhoduje o budoucím vývoji firmy.

Nejdůležitější kroky pro aplikaci ABC ve firmě jsou (Popesko 2009, s. 101): 
- V prvním kroku je vynaložený ekonomický zdroj, v tomto případě nepřímý náklad, přiřazen k jednotlivým definovaným aktivitám. Přiřazení se provádí na základě vztahové veličiny nákladů (Resouce Cost Driver), která vymezuje způsob přepočtu nákladů z účetní evidence na jednotlivé definované aktivity.

- V druhém kroku se zjistí celkové náklady na jednotlivé aktivity (Cost Pool), vymezí se vztahová veličina aktivity, resp. nákladový nositel (Activity-Cost Driver) a stanoví se náklady na jednotku aktivity.

- Ve třetím kroku se určí náklady na předmět alokace, tj. nákladový objekt (výkon, službu, zákazníka) na základě nákladů na jednotku aktivity a objemu těchto jednotek, které jsou objekty alokace spotřebovány.

Procesní a produktový pohled na aktivity a náklady je zobrazen na obrázku 3. Z obrázku jsou zřetelně vidět prŕislušné souvislosti (Petřík 2007, s. 167)

Obrázek 3: Schéma procesní a produktové linie ABC

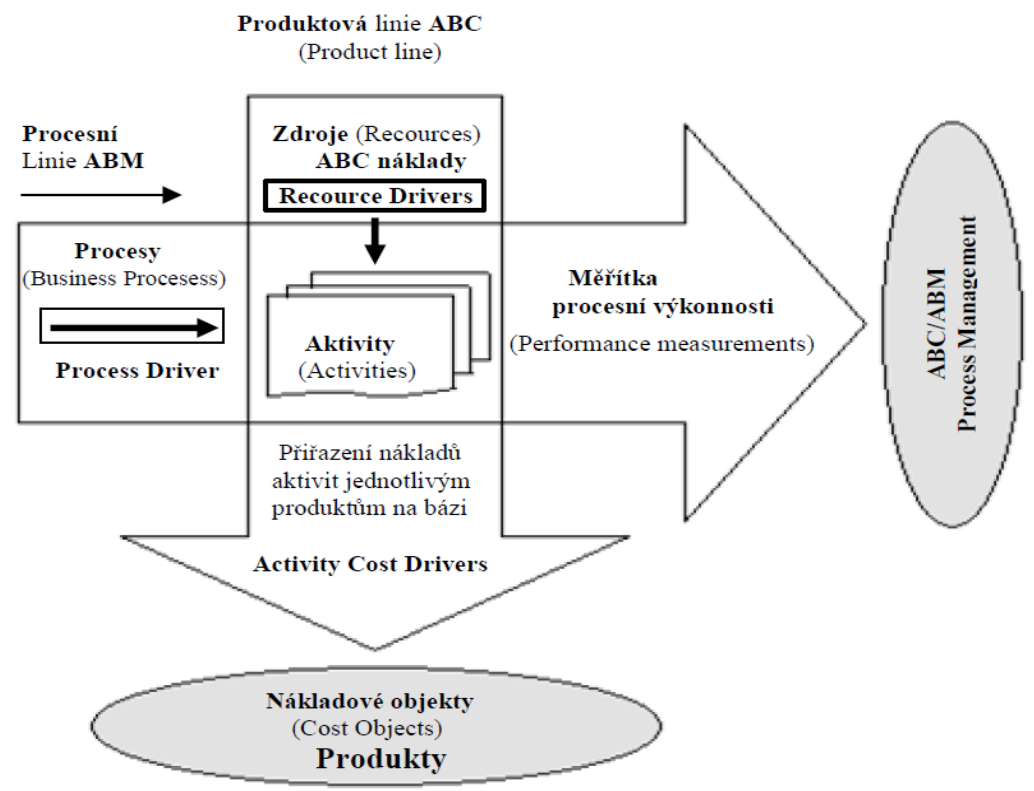

Zdroj: Petř́k (2007, s. 167)

Užitečnost zavedení metody $\mathrm{ABC}$ tkví především $\mathrm{v}$ tom, že se mohou náklady řídit jednak z operativního pohledu, což představuje:

- důkladné nákladové analýzy aktivit a procesů se zaměřením na kontinuální a systematické zlepšování operativní efektivity a produktivity ústící v trvalé zvyšování výkonnosti,

- rrízení nevyužité kapacity, tedy na stálý objem výstupů použití méně vstupů (zdrojů),

- určení přidané hodnoty $\mathrm{k}$ jednotlivým aktivitám a procesům,

tak i z pohledu strategického, kdy metoda $A B C$ přechází v metodu ABM (Activity-based Management), což umožňuje:

- regulaci množství zdrojů a tím i objemu provozních, taktických a strategických aktivit a následných procesů,

- utlumení, či odstranění neproduktivních procesů,

- rozhodování o produktových řadách se zaměřením na vyšší ziskovost (Petřík 2007) 
Pokud však firma používá pouze metodu $A B C$, není schopna do svého sledování a vyhodnocování analýz zahrnout strategické a nefinanční prvky, které jsou součástí metody BSC. Spojení metod BSC a $A B C$ tedy přináší přesnější metriky, přesnější stanovení jak operativních i strategických měřítek a ve vzájemné kombinaci pak snadnější plnění stanovené strategie a dosažení konkurenční výhody (Johnson, 2007).

Přesnost informací o nákladech získaných z metody $\mathrm{ABC}$ je často vnímána jako podpůrný měřící systém pro úspěšnou implementaci metody BSC. Výsledky studie provedené Maigou a Jakobsem (Maiga, 2003) ukázaly, že interakce mezi čtyřmi perspektivami BSC a ABC má synergické účinky pozitivně ovlivňující především výkonnost. Má také pozitivní vliv na kvalitu výrobků a spokojenost zákazníka. Interakcí obou metod se však nenašel významný pozitivní vliv na prodejní marži.

James (2010) ve své studii potvrdil, že vzájemné působení metod ABC a BSC zlepšuje organizační výkonnost, zákaznickou výkonnost a také inovační výkonnost firmy. Řízení nákladů firem, které používají obě metody, je kvalitnější než u firem, které používají jen jednu z těchto metod. Ale vyšší výkonnost je závislá především na typu strategie.

Pozitivní výsledek interakce metod BSC a $\mathrm{ABC}$ pro zvyšování výkonnosti prezentoval také Shwu-Ing Wu (2012). Na základě studie hodnocení výkonnosti a srovnání podniků, které obdržely nebo neobdržely certifikaci ISO, vyplynul závěr, že pozitivní výsledek pro akreditaci ISO byla prokázána při použití obou metod, které udávají jasný směr a hodnotu výkonnosti.

\section{Dílčí závěr k teoretickému rámci.}

Metoda $\mathrm{ABC}$, slouží k vyhodnocování nákladovostí jednotlivých aktivit a přiřazování nákladů nákladovým objektům. Užitečnost implementace této metody tkví především $\mathrm{v}$ tom, že se mohou náklady rrídit jednak z operativního pohledu (nákladové analýzy aktivit a procesů a systematické zlepšování operativní efektivity), ale i z pohledu strategického (rozhodování o produktových řadách se zaměřením na vyšší ziskovost). Spojení metod BSC a ABC přináší přesnější metriky, přesnější stanovení jak operativních i strategických měřítek a v kombinaci vytváří synergický efekt při řízení výkonnosti firmy.

\section{Praktická implementace metody $\mathrm{ABC}$ ve výrobní firmě}

$\mathrm{Na}$ základě př́padové studie implementace metody $\mathrm{ABC}$ do výrobní firmy je $\mathrm{v}$ této části př́spěvku ukázáno, jak tato metoda procesního řízení nákladů dovede rozklíčovat jednotlivé režijní náklady firmy do procesních aktivit a dále pak náklady aktivit rozložit do jednotlivých produktových řad. Studie je aplikována ve firmě vyrábějící nástroje do otvorů a vzhledem k utajení skutečných nákladů jsou uvedeny fiktivní hodnoty tak, že výsledky neodpovídají skutečnému stavu. Přesto poměrová čísla produktových řad zůstala zachována.

Před samotnou implementací metody $\mathrm{ABC}$ byla provedena změna procesní mapy, která byla autorem upravena do takové podoby, aby množství aktivit nepřesáhlo rámec srozumitelnosti a přehlednosti při rozdělení jednotlivých nákladových položek. Protože se jedná o výrobní firmu, většinu nákladů tvoří náklady výroby. Ale i v samotné výrobě se vyskytuje veliké množství režijních nákladů, alokovaných ve výrobní režii.

Náklady, které ve firmě existují, jsou rozděleny na př́ímé náklady a režijní náklady. Mezi př́mé náklady patří náklady na materiál, jednicové mzdy a také externí kooperace. $\mathrm{S}$ těmito náklady se $\mathrm{v}$ modelu $\mathrm{ABC}$ matice nepočítá, protože metoda $\mathrm{ABC}$ se zabývá jen režijními náklady. V samotné procesní aktivitě - výroba zbývá ještě veliká část nákladů patřící 
do skupiny výrobní režie. Zde se setkáme např́klad s náklady: spotřeba nástrojů a nářadí, mazadla, chladící oleje, náklady na materiál pro opravy a udržování strojů a další. Protože je ve firmě velké množství strojů (350 ks) a nelze ke každému stroji přiřadit měřící zařízení ke sledování spotřeby elektrické energie, bylo rozhodnuto, že celková hodnota spotřeby elektrické energie nebude přiřazena jako prŕmý náklad, ale vzhledem k tomu, že spotřeba jednotlivých strojů se pohybuje přibližně na stejné hodnotě, tedy kolem průměrné hodnoty na jeden stroj, byly i náklady spotřeby energie přiřazeny k výrobní režii. Další, ne nepodstatnou položkou nákladů ve výrobě, jsou režijní pracovníci. Mezi tyto režijní pracovníky patří především pracovníci ve výrobním středisku kalení, pískování, rovnání, odmašt'ování, pasivování značení a stejně tak i pracovníci vykonávající mezioperační manipulaci a také údržbáři a elektrikáři. Poslední velikou položkou výrobní režie je nákladová položka odpis strojů. Vzhledem $\mathrm{k}$ tomu, že firma $\mathrm{v}$ uplynulých 4 letech investovala nemalé peníze do modernizace strojů a technologie, je tato položka významná a ovlivňuje tak celkový výsledek.

V tabulce 1 je znázorněno rozložení všech nákladových účtů na jednotlivé aktivity. Klíč přiřazení nákladů $\mathrm{k}$ jednotlivým aktivitám byl proveden na základě revize procesů a činností.

Tabulka 1: Převod nákladových účtů na aktivity (procesy)

\begin{tabular}{|c|c|c|c|c|c|c|c|c|c|c|c|c|c|c|c|}
\hline 2015 & nazev & 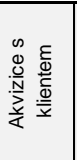 & 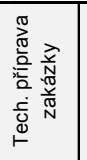 & 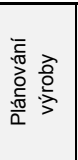 & 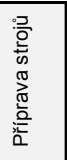 & 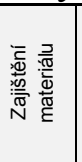 & $\begin{array}{l}\frac{0}{0} \\
\frac{0}{0} \\
\frac{0}{0} \\
\frac{\pi}{\pi} \\
\frac{\pi}{2} \\
\text { की }\end{array}$ & 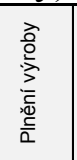 & 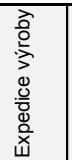 & 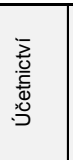 & 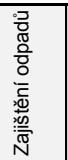 & $\begin{array}{l}\frac{5}{\pi} \\
\frac{0}{\pi} \\
\frac{\pi}{0} \\
\text { की }\end{array}$ & 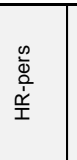 & 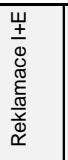 & $\begin{array}{l}\text { Celkový } \\
\text { součet }\end{array}$ \\
\hline \multirow{3}{*}{ 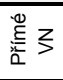 } & Mzda Jed Zam & & & & & & & 10550 & & & & & & & 10550 \\
\hline & Ṕ̛̛íý materiál na výrobu & & & & & & & 20747 & & & & & & & 20747 \\
\hline & Kooperace & & & & & & & 345 & & & & & & & 345 \\
\hline \multicolumn{2}{|c|}{ Přímé VNCelkem } & 0 & 0 & 0 & 0 & $\begin{array}{ll}0 \\
\end{array}$ & 0 & 31643 & 0 & 0 & 0 & 0 & 0 & 0 & 31643 \\
\hline \multirow{16}{*}{ 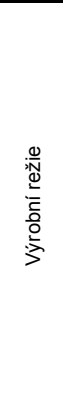 } & Mzda Rež Zam & & & & & & & 8116 & & & & & & & 8116 \\
\hline & Spotřeba nářadí & & & & & & & 1731 & & & & & & & 1731 \\
\hline & \begin{tabular}{|l|} 
Obaly a materiál na obaly \\
\end{tabular} & & & & & & & & 756 & & & & & & 756 \\
\hline & \begin{tabular}{|l|} 
Náklady na pořizení materiálu \\
\end{tabular} & & & & & 61 & & & & & & & & & 61 \\
\hline & Brusivo, diamanty & & & & & & & 1460 & & & & & & & 1460 \\
\hline & Mater. na opr. a udrž. strojů & & & & 1317 & & & & & & & & & & 1317 \\
\hline & Mazadla a chl.oleje,provoz.hmoty & & & & & & & 787 & & & & & & & 787 \\
\hline & \begin{tabular}{|l|} 
日. energie, voda, topení \\
\end{tabular} & & & & & & & 4440 & & & & & & & 4440 \\
\hline & Opravy udržováni strojů,príist. & & & & 488 & & & & & & & & & & 488 \\
\hline & Ostření a broušení nářadí & & & & & & & 226 & & & & & & & 226 \\
\hline & Likvidace odpadů z výr. techn. & & & & & & & & & & 279 & & & & 279 \\
\hline & Ostatni služby & & & & & & & & & 602 & & & & & 602 \\
\hline & Ostatni osobni nákl. & & & & & & & 231 & & & & & & & 231 \\
\hline & \begin{tabular}{|l|} 
Prebrusy MV \\
\end{tabular} & & & & & & & 367 & & & & & & & 367 \\
\hline & Zmetky - sklad HV & & & & & & & & & & & & & 31 & 31 \\
\hline & Odpisy HDM & & & & & & & 9332 & & & & & & & 9332 \\
\hline \multicolumn{2}{|c|}{ Výrobní režie Celkem } & 0 & 0 & 0 & 1805 & 61 & 0 & 26690 & 756 & 602 & 279 & 0 & 0 & 31 & 30224 \\
\hline \multirow{6}{*}{ 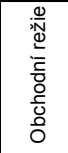 } & Mzda Thp Zam & 457 & & & & & & & 533 & 306 & & & & 304 & 1599 \\
\hline & Materiál na propagaci & 114 & & & & & & & & & & & & & 114 \\
\hline & Služební cesty & 101 & & & & & & & & & & & & & 101 \\
\hline & Propagačni služby & 17 & & & & & & & & & & & & & 17 \\
\hline & \begin{tabular}{|l|l|} 
Přepravné zboži,HV a NV \\
\end{tabular} & & & & & & & & 263 & & & & & & 263 \\
\hline & Reklamni předměty do $500 \mathrm{Kč} / \mathrm{ks}$ & 23 & & & & & & & & & & & & & 23 \\
\hline \multicolumn{2}{|c|}{ Obchodní režie Celkem } & 712 & 0 & 0 & 0 & 0 & 0 & 0 & 796 & 306 & 0 & 0 & 0 & 304 & 2118 \\
\hline \multirow{21}{*}{ 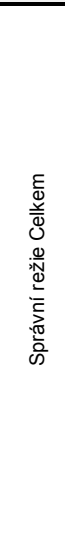 } & Mzda Thp Zam & 485 & 1172 & 1491 & & 418 & 326 & & & 277 & 237 & 344 & 284 & & 5034 \\
\hline & DHM & & & & & 216 & & & & & & & & & 216 \\
\hline & PHM k osobnim doprav. prostř. & 31 & & & & & & & & & & & & & 31 \\
\hline & Mater. na opr. a udrž. budov & & & & & & 79 & & & & & & & & 79 \\
\hline & Kancelářské potřeby & & & & & & & & & & & & 64 & & 64 \\
\hline & Ostatní režijni materiál & & & & & & 101 & & & & & & & & 101 \\
\hline & Opravy udržování budov,staveb & & & & & & 545 & & & & & & & & 545 \\
\hline & \begin{tabular}{|l|} 
Náklady na infor.systém \\
\end{tabular} & & & & & & & & & & & 81 & & & 81 \\
\hline & Ostraha & & & & & & 535 & & & & & & & & 535 \\
\hline & \begin{tabular}{|l|} 
Dopravní služby \\
\end{tabular} & & & & & & & & 33 & & & & & & 33 \\
\hline & DNM & & & & & & & & & & & 27 & & & 27 \\
\hline & \begin{tabular}{|l|} 
Nájemné a uklid. sl. \\
\end{tabular} & & & & & & 41 & & & & & & & & 41 \\
\hline & \begin{tabular}{|l|} 
Porad.služba-daně,audit,revize \\
\end{tabular} & & & & & & & & & 221 & & & & & 221 \\
\hline & Výkony spojů-poštovné,telef. & & & & & & & & & & & & 146 & & 146 \\
\hline & Výdaje strav., hygienu, pomůcky & & & & & & & & & & & & 545 & & 545 \\
\hline & Daň z nemovitosti & & & & & & & & & 154 & & & & & 154 \\
\hline & \begin{tabular}{|l} 
Ostatni prov. nákl. plac. org. \\
\end{tabular} & & & & & & & & & 217 & & & & & 217 \\
\hline & Odp.softw are nad 60000 Kč & & & 343 & & & & & & & & & & & 343 \\
\hline & Odp.ocen.práv nad 60000 Kč & & 109 & & & & & & & & & & & & 109 \\
\hline & Odpisy budov, hal a staveb & & & & & & 659 & & & & & & & & 659 \\
\hline & Ost.finan.náklady plac.organ. & & & & & & & & & 257 & & & & & 257 \\
\hline \multirow{3}{*}{ Správn } & írežie Celkem & 516 & 1281 & 1834 & 0 & 634 & 2286 & 0 & 33 & 1126 & 237 & 452 & 1039 & 0 & 9438 \\
\hline & Celkem nákladů součet & 1228 & 1281 & 1834 & 1805 & 696 & 2286 & 58332 & 1586 & 2034 & 516 & 452 & 1039 & 334 & 73423 \\
\hline & Celkem režijnich nákladů & 1228 & 1281 & 1834 & 1805 & 696 & 2286 & 26690 & 1586 & 2034 & 516 & 452 & 1039 & 334 & 41780 \\
\hline
\end{tabular}

Zdroj: vlastní zpracování 
Největší podíl nákladů však v tabulce 1 zůstalo v aktivitě výroba, proto bylo nutné dále rozložit tuto aktivitu, což je provedeno v tabulce 2 . Náklady výrobní režie jsou rozděleny pomocí klíče skutečných normohodin $(\mathrm{Nh}) \mathrm{v}$ případě produktivních operací, jako jsou dělení, soustružení, broušení, ostření, vybrušování, což jsou stěžejní operace výroby. Těmto operacím přísluší i nejvyšší odpisy strojů, protože právě v těchto klíčových činnostech byly technologie nejvíce zmodernizovány. $Z$ toho důvodu je zde alokováno největší množství nákladů. Režijní pracovníci a ostatní režijní náklady jsou přiřazeny $\mathrm{k}$ aktivitám, jako jsou kalení, pískování, odmaštování, pasivace, tedy neproduktivním, ale nutným operacím. Nutno upozornit, že vysoká hodnota odběru elektrické energie byla přiřazena kalení, které je značně energeticky náročné.

Tabulka 2: Rozčlenění aktivity „výroba“ na jednotlivé výrobní operace

\begin{tabular}{|c|c|c|c|c|c|c|c|c|c|c|c|c|c|c|c|c|c|}
\hline & & 冚 & 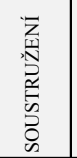 & 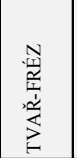 & 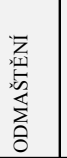 & $\begin{array}{l}\underset{\mathrm{Z}}{\mathrm{u}} \\
\vec{\Xi}\end{array}$ & $\begin{array}{l}z \\
\frac{z}{2} \\
0 \\
\frac{\pi}{2} \\
\frac{3}{2}\end{array}$ & 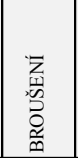 & 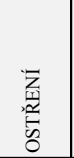 & 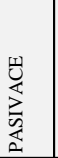 & 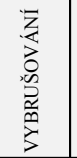 & $\begin{array}{l}\longleftarrow \\
0 \\
o \\
\vdots \\
0 \\
0\end{array}$ & 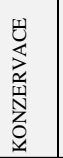 & 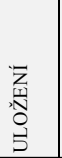 & 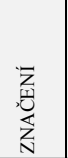 & 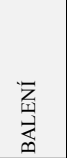 & 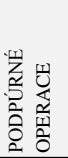 \\
\hline & & Nhod & Nhod & Nhod & & & & Nhod & Nhod & & Nhod & & & & P Ks & P Ks & Nhod \\
\hline & $\mathrm{NH}$ & 3828 & 15700 & 8264 & 0 & 0 & 0 & 24963 & 6033 & 0 & 9705 & 0 & 0 & 0 & 0 & 0 & 2835 \\
\hline Mzda Rež Zam & 8116 & & & & 459 & 1168 & 671 & & & 369 & & 988 & 329 & 306 & 934 & 1397 & 1495 \\
\hline Spotřeba nářadí & 1731 & 271 & 434 & 894 & & 12 & & & & & & & & & & & 120 \\
\hline Brusivo, diamanty & 1460 & & & & & & & 487 & 243 & & 730 & & & & & & \\
\hline Mazadla a chl.oleje,prov.hm. & 787 & 124 & 141 & 15 & 12 & 63 & 15 & 106 & 47 & 2 & 236 & & 12 & & & & 14 \\
\hline El. energie, voda, topení & 4440 & 183 & 752 & 396 & 5 & 947 & 6 & 1195 & 289 & 49 & 465 & 2 & 8 & 1 & 6 & 1 & 136 \\
\hline Ostření a broušení nářadí & 226 & & & & & & & 118 & 89 & & & & & & & & 19 \\
\hline Ostatní osobní nákl. & 231 & & & & 13 & 33 & 19 & & & 10 & & 28 & 9 & 9 & 27 & 40 & 42 \\
\hline Přebrusy MV & 367 & & & & & & & 298 & 35 & & & & & & & & 34 \\
\hline Odpisy HDM & 9332 & 269 & 1873 & 34 & 468 & & 340 & 2437 & 1468 & & 1643 & 205 & 25 & & 246 & & 324 \\
\hline Výrobní režie Celkem & 26690 & 847 & 3200 & 1339 & 957 & 2223 & 1051 & 4641 & 2171 & 430 & 3074 & 1223 & 383 & 316 & 1213 & 1438 & 2184 \\
\hline
\end{tabular}

Zdroj: vlastní zpracování

Z vyhodnocení stěžejní a nákladově nejvíce zatížené aktivity dominuje broušení a vybrušování. $Z$ hlediska př́čin vzniku nákladu a řízení je důležité zaměřit se na tyto aktivity co nejvíce, protože horší produktivitou a výkonností může dojít k enormnímu zvýšení nákladů.

Tabulka 3 ukazuje další transformaci nákladů, tentokrát už z aktivit na nákladové objekty, což jsou jednotlivé produktové řady výrobků. K rozdělení procesních aktivit na nákladové objekty je použito několika druhů vztahových veličin aktivit, resp. nákladových nositelů (aktivity-cost drivers). Jedním $\mathrm{z}$ nich je počet normohodin, jež vychází propočtem pracovních a seřizovacích časů na normovaných operacích. Výpočet množství normohodin strávených na daných výrobních operacích jednotlivými výrobky byl proveden podle pracovních postupů a skutečně provedených a zaznamenaných operací v informačním systému (IS) firmy. Výsledné hodnoty byly dosazeny do tabulky metody ABC. Výrobní firma, která má ve svém výrobkovém portfoliu více jak 6500 typo-rozměrů (tedy nabízených výrobků lišící se typem a její rozměrovou řadou, př́kladně od ø $1 \mathrm{~mm}$ až do ø $100 \mathrm{~mm}$ odstupňované po $0,1 \mathrm{~mm}$ v menších rozměrech a $1 \mathrm{~mm}$ ve větších rozměrech), se bez takového sofistikovaného informačního systému samozřejmě neobejde.

Dalším typem nákladového nositele je počet zakázek, v našem př́ípadě počet výrobních př́kazů, pod kterými prochází zakázka celou výrobou. Tato vztahová veličina je vhodná pro rozčlenění obchodních aktivit a některých režijních aktivit ve výrobě. Posledním typem nákladového nositele je počet kusů, který je použit u zbylých aktivit. Nutno upozornit ještě na rozdělení nákladů aktivity technická prř́prava zakázky, kde k náročnosti př́ípravy výroby 
speciálů je tomuto nákladovému objektu přiřazeno $80 \%$ nákladů na místo $5 \%$ u všech vrtáků a $10 \%$ u nástrojů.

Tabulka 3: Rozčlenění aktivit na nákladové objekty (skupiny výrobků)

\begin{tabular}{|c|c|c|c|c|c|c|c|c|c|c|}
\hline & & & \multirow{2}{*}{\multicolumn{3}{|c|}{ Vrtáky }} & \multirow{3}{*}{$\begin{array}{l}\text { Nářadí } \\
\text { Nářadí }\end{array}$} & \multirow{3}{*}{\begin{tabular}{l|} 
Speciály \\
Speciály
\end{tabular}} & & & \\
\hline & & & & & & & & & & \\
\hline & & Náklad & Frézované & Tvářené & Vybrušov. & & & & & \\
\hline & & $\mathrm{Ks}$ & 64086 & 1017851 & 2049528 & 124255 & 91950 & & & \\
\hline & & Nhod & 8742 & 12827 & 30137 & 14096 & 5526 & & & \\
\hline Activita & COST Driver & P Zak & 1009 & 543 & 2551 & 1484 & 1344 & cena/Nh & cena/ks & cena/zak. \\
\hline Akvizice s klientem & Počet zak & 1228 & 179 & 96 & 452 & 263 & 238 & $17,22 \mathrm{Kč}$ & $0,37 \mathrm{Kč}$ & $177,18 \mathrm{Kč}$ \\
\hline Tech. př́íprava zakázky & techn. & 1281 & 64 & 64 & 64 & 128 & 961 & $17,96 \mathrm{Kč}$ & $0,38 \mathrm{Kč}$ & $184,81 \mathrm{Kč}$ \\
\hline Plánování výroby & Počet zak & 1834 & 267 & 144 & 675 & 393 & 356 & $25,72 \mathrm{Kč}$ & $0,55 \mathrm{Kč}$ & $264,64 \mathrm{Kč}$ \\
\hline Příprava strojů & Nhod & 1805 & 221 & 325 & 763 & 357 & 140 & $25,31 \mathrm{Kč}$ & $0,54 \mathrm{Kč}$ & \\
\hline Zajištění materiálu & Počet zak & 696 & 101 & 54 & 256 & 149 & 135 & $9,75 \mathrm{Kč}$ & $0,21 \mathrm{Kč}$ & $100,35 \mathrm{Kč}$ \\
\hline Zajištění budov & Počet ks & 2286 & 44 & 695 & 1399 & 85 & 63 & $32,05 \mathrm{Kč}$ & $0,68 \mathrm{Kč}$ & \\
\hline Plnění výroby & Nhod & 26690 & 3271 & 4800 & 11277 & 5274 & 2068 & $374,18 \mathrm{Kč}$ & 7,97 Kč & \\
\hline \begin{tabular}{l|l} 
DĚLENÍ \\
\end{tabular} & Nhod & 847 & 104 & 152 & 358 & 167 & 66 & $11,88 \mathrm{Kč}$ & $0,25 \mathrm{Kč}$ & \\
\hline SOUST RUŽENÍ & Nhod & 3200 & 392 & 575 & 1352 & 632 & 248 & $44,86 \mathrm{Kč}$ & $0,96 \mathrm{Kč}$ & \\
\hline T VAŘ-FRÉZ & Nhod & 1339 & 164 & 241 & 566 & 265 & 104 & $18,77 \mathrm{Kč}$ & $0,40 \mathrm{Kč}$ & \\
\hline ODMAŠTĚNÍ & Počet zak & 957 & 139 & 75 & 352 & 205 & 186 & $13,42 \mathrm{Kč}$ & $0,29 \mathrm{Kč}$ & $138,08 \mathrm{Kč}$ \\
\hline KALENÍ & Počet zak & 2223 & 324 & 174 & 818 & 476 & 431 & $31,17 \mathrm{Kč}$ & $0,66 \mathrm{Kč}$ & $320,76 \mathrm{Kč}$ \\
\hline \begin{tabular}{|l} 
PÍSKOVÁNÍ \\
\end{tabular} & Počet zak & 1051 & 153 & 82 & 387 & 225 & 204 & $14,74 \mathrm{Kč}$ & $0,31 \mathrm{Kč}$ & $151,65 \mathrm{Kč}$ \\
\hline BROUŠENÍ & Nhod & 4641 & 569 & 835 & 1961 & 917 & 360 & $65,06 \mathrm{Kč}$ & $1,39 \mathrm{Kč}$ & \\
\hline OST ŘENÍ & Nhod & 2171 & 266 & 390 & 917 & 429 & 168 & $30,44 \mathrm{Kč}$ & $0,65 \mathrm{Kč}$ & \\
\hline PASIVACE & Počet zak & 430 & 63 & 34 & 158 & 92 & 83 & $6,04 \mathrm{Kč}$ & $0,13 \mathrm{Kč}$ & $62,11 \mathrm{Kč}$ \\
\hline VYBRUŠOVÁNÍ & Nhod & 3074 & 377 & 553 & 1299 & 607 & 238 & $43,09 \mathrm{Kč}$ & $0,92 \mathrm{Kč}$ & \\
\hline KONTROLA & Počet ks & 1223 & 23 & 372 & 749 & 45 & 34 & $17,15 \mathrm{Kč}$ & $0,37 \mathrm{Kč}$ & \\
\hline KONZERVACE & Počet zak & 383 & 56 & 30 & 141 & 82 & 74 & $5,37 \mathrm{Kč}$ & $0,11 \mathrm{Kč}$ & $55,31 \mathrm{Kč}$ \\
\hline ULOŽENÍ & Počet ks & 316 & 6 & 96 & 193 & 12 & 9 & $4,43 \mathrm{Kč}$ & $0,09 \mathrm{Kč}$ & \\
\hline ZNAČENÍ & Počet ks & 1213 & 23 & 369 & 742 & 45 & 33 & $17,00 \mathrm{Kč}$ & $0,36 \mathrm{Kč}$ & \\
\hline BALENÍ & Počet ks & 1438 & 28 & 437 & 880 & 53 & 39 & $20,16 \mathrm{Kč}$ & $0,43 \mathrm{Kč}$ & \\
\hline PODPÚRNÉ OPERACE & Nhod & 2184 & 268 & 393 & 923 & 432 & 169 & $30,62 \mathrm{Kč}$ & $0,65 \mathrm{Kc}$ & \\
\hline Expedice výroby & Počet ks & 1586 & 30 & 482 & 971 & 59 & 44 & $22,23 \mathrm{Kč}$ & $0,47 \mathrm{Kč}$ & \\
\hline Účetnictví & Počet ks & 2034 & 39 & 618 & 1245 & 75 & 56 & $28,51 \mathrm{Kč}$ & $0,61 \mathrm{Kč}$ & \\
\hline Zajištění odpadů & Počet ks & 516 & 10 & 157 & 316 & 19 & 14 & $7,23 \mathrm{Kč}$ & $0,15 \mathrm{Kč}$ & \\
\hline Správa ICT & Počet ks & 452 & 9 & 137 & 277 & 17 & 12 & $6,34 \mathrm{Kč}$ & $0,14 \mathrm{Kč}$ & \\
\hline HR-pers & Počet ks & 1039 & 20 & 316 & 636 & 39 & 29 & $14,56 \mathrm{Kč}$ & $0,31 \mathrm{Kč}$ & \\
\hline Reklamace I+E & Počet ks & 334 & 6 & 102 & 205 & 12 & 9 & $4,68 \mathrm{Kč}$ & $0,10 \mathrm{Kč}$ & \\
\hline Celkem & & 41780 & 3944 & 7998 & 19055 & 6281 & 4501 & $585,74 \mathrm{Kč}$ & $12,48 \mathrm{Kc}$ & \\
\hline
\end{tabular}

Zdroj: vlastní zpracování

Z tabulky 3 lze pak snadno vyčíst hodnoty hodinových, případně kusových nákladů na aktivitu, podle nichž lze stanovit jednotlivá výkonnostní kritéria pro další sledování. Na těchto základech lze také stanovit motivační kritéria propojená se strategií firmy pomocí metody BSC. I v této podobě se potvrzuje, že nejvyšší hodnota nákladů vztažená na hodinový výkon, je u broušení, vybrušování a soustružení. Je však nutné blíže se zaměřit také na hodnoty nákladů akvizice s klientem, plánování výroby, př́prava strojů a správa budov a v neposlední řadě také vedení účetnictví. Všude zde jsou hodnoty vysoké.

Tabulka 4 ukazuje, jak metoda $\mathrm{ABC}$ po produktové linii přechází z operativního řízení nákladi̊ na strategické. Rozbor nákladových objektů (porovnáním skutečných nákladů s výkony) slouží jako podklad pro strategické rozhodování, které produktové řady jsou pro firmu př́nosem, u kterých je nutné upravit prodejní cenu a které je naopak vhodné úplně z výrobkového portfolia vyřadit. Strategické rozhodnutí však nelze udělat jen na základě analýzy ziskovosti. Do rozhodovacího procesu musí vstoupit analýza oborového prostředí firmy, minimálně zjištění cenové hladiny výrobků na trhu, síly odběratelů, stav konkurence. 
Tabulka 4: Rozbor nákladových objektů

\begin{tabular}{|c|c|r|r|r|r|r|r|r|r|r|r|}
\hline \multicolumn{2}{|c|}{ Nákladový objekt } & Počet ks & Počet Nh & Počet VP & $\begin{array}{c}\text { Režjijní } \\
\text { náklady }\end{array}$ & $\begin{array}{c}\text { Materiál. } \\
\text { náklady }\end{array}$ & $\begin{array}{l}\text { Jednicové } \\
\text { mzdy }\end{array}$ & $\begin{array}{c}\text { Celkem } \\
\text { náklady }\end{array}$ & Výkony & \multicolumn{1}{c|}{ ZISK } & $\begin{array}{c}\text { Míra } \\
\text { zisku }\end{array}$ \\
\hline \multirow{3}{*}{ Vrtáky } & Frézované & 64086 & 8742 & 1009 & 3944 & 3809 & 1489 & 9243 & 12994 & $\mathbf{3 7 5 2}$ & $\mathbf{4 0 , 5 9 \%}$ \\
\cline { 2 - 13 } & Tváŕené & 1017851 & 12827 & 543 & 7998 & 3857 & 1750 & 13605 & 12002 & $\mathbf{- 1 6 0 3}$ & $\mathbf{- 1 1 , 7 8 \%}$ \\
\cline { 2 - 12 } & Vybrušov. & 2049528 & 30137 & 2551 & 19055 & 10648 & 4134 & 33838 & 36430 & $\mathbf{2 5 9 2}$ & $\mathbf{7 , 6 6 \%}$ \\
\hline Náradí & Nářadí & 124255 & 14096 & 1484 & 6281 & 1686 & 2196 & 10163 & 14738 & $\mathbf{4 5 7 5}$ & $\mathbf{4 5 , 0 2 \%}$ \\
\hline Speciály & Speciály & 91950 & 5526 & 1344 & 4501 & 746 & 981 & 6229 & 5937 & $\mathbf{- 2 9 2}$ & $\mathbf{- 4 , 6 9 \%}$ \\
\hline
\end{tabular}

Zdroj: vlastní zpracování

Z výsledků tabulky 4 je patrné, že nejvíce ztrátovým nákladovým objektem jsou tvářené vrtáky, které již zasahují pod hranici ziskovosti. Nepř́iemným zjištěním je i nedobrá situace u speciálních nástrojů, na kterých firma směrem k zákazníkům demonstrovala svou technickou dokonalost a tyto výrobky jsou mimo jiné i podpůrným programem pro prodej standartních výrobků. Nižší míra zisku u vybrušovaných výrobků je dána prodejními cenami na trhu, kde v tomto sortimentu je silné konkurenční prostředí. Tento produkt je však hlavním produktem a vyčleněním z výroby by firmě způsobilo rapidní snížení objemu tržeb a neschopnost pokrýt fixní náklady. Proto je potřebné spíše zrevidovat produktivitu aktivit spojených s touto výrobkovou řadou.

\section{Dílčí závěr z výsledků implementace metody $\mathrm{ABC}$}

Výsledky implementace metody $\mathrm{ABC}$ ve firmě ukázaly, že nejvíce jsou režijními náklady ve výrobě zatíženy tři stěžejní operace, a to soustružení, broušení a vybrušování. Z ostatních režijních nákladů je potřeba hlídat především procesy akvizice se zákazníky, plánování výroby, př́pravu strojů, zajištění budov a vedení účetnictví. Zde je nutná revize procesu i jednotlivých nákladových účtů. Pokud by tyto stěžejních aktivity nebyly řízeny, mohlo by to mít neblahý vliv na ekonomiku firmy. Z vyhodnocení nákladových objektů vyplynulo, že v kategorii tvářených vrtáků jsou přiřazené skutečné náklady vyšší, než vlastní př́imy $\mathrm{z}$ tržeb. Tato kategorie výrobků firmě tedy působí ztrátu a to více než $-11 \%$ (míra zisku na nákladový objekt). Tím také snižuje celkový zisk firmy. Řešením může být úprava prodejních cen. V tomto případě to však není reálné, protože konkurenční cenová hladina je ještě o něco nižší. Východiskem je tedy omezení výroby tvářených vrtáků nebo úplné opuštění tohoto segmentu trhu. Podobně, i když s menší ztrátou jsou na tom i speciální nástroje, na kterých však firma směrem $\mathrm{k}$ zákazníkům demonstruje svou technickou dokonalost. $\mathrm{V}$ tomto př́padě by však nebylo správné opouštět $\mathrm{s}$ tímto typem výrobku trh, protože tento sortiment tvoří podpůrný program pro prodej standartních výrobků, jakým je nosný program firmy - vybrušované vrtáky.

\section{Problémy implementace systému $\mathrm{ABC}$ a nedostatky pro řízení nákladů a výkonnosti}

I když při implementaci a následném zkušebním provozu bylo zjištěno několik problémů a nedostatků, je možno říci, že systém procesního řízení nákladů pomocí metody $A B C$ je vhodným nástrojem pro identifikaci nákladů, po nalezení příčin vzniku vícenákladů a výborným pomocníkem v rukou zkušeného manažera. Systém však má i své nedostatky, které se dají shrnout do následujících bodů:

- Základním problémem při implementaci se jeví problém vyčlenění potřebných dat správným a věrohodným způsobem. Vzhledem k tomu, že ne všechny firmy mají v rukou vhodný informační systém, může nastat situace, kdy jednotlivé tabulky jsou naplněny daty, ale výsledek neodpovídá realitě a tedy i samotné rozhodování může být nesprávné.

- Kritickým místem je také správné určení uvedených procesních aktivit. Pro přehlednost je zapotřebí stanovit optimální množství nákladových aktivit, ale chybí pravidla pro 
stanovení jejich počtu a vhodný výběr aktivity, které objektivně ukáží příčiny vzniku nákladů.

- Dalším kritickým místem implementace je přesné rozčlenění všech nákladových položek do aktivit. V důsledku nesprávného přidělení pak nastává situace, kdy je pozornost zaměřena na aktivitu, která z celkového pohledu nemusí být prioritní a rozhodování je pak zkreslené a zavádějící.

- Důležitým faktorem správného určení hodnot nákladů aktivit i nákladových objektů je přesné určení nákladových nositelů a vzorce jejich výpočtu. Správný výběr má vliv na kalkulaci nákladů a správně určený vzorec pak na jejich porovnávací hodnotu.

- Dalším kritickým bodem metody ABC je, že téměř v žádném ohledu nebere vliv na makro okolí a především pak oborové okolí firmy. Vliv zákazníků, konkurence, trhu, ale i segmenty zásobovací, distribuční a marketingové mohou výrazně ovlivnit příčinu a výši nákladů. $\mathrm{Z}$ ekonomického hlediska se tyto náklady zdají být plýtváním, ale trh je bohužel natolik ovlivňuje, že pro konkurenční boj jsou nezbytné.

- Implementace metody $\mathrm{ABC}$ je náročnou aktivitou, protože zabírá čas klíčových pracovníků a propojení se všemi systémy ve firmě vyvolává další náklady. Zapojení všech manažerů a vlastníků procesů je nezbytné. V neposlední řadě vzájemné propojení procesů s IS firmy je technicky náročné.

- Užití metody $A B C$ není jen statické a nezůstává po celou dobu zavedení v ustálené podobě. Jedná se o živý systém, zaměřený na neustále prováděné změny, počínaje strategickými změnami a konče např́klad změnami procesů k vyšší optimalizaci. $Z$ toho důvodu systém vyžaduje neustálou kontrolu provedených změn a upřesňování podmínek.

- Př́ičinou nesprávného použití této metody může být i neochota managementu a všech zainteresovaných osob podílet se na správě celého systému.

- Mezi problémy lze zařadit rovněž neochotu ostatních pracovníků sdílet a plnit kritéria výkonnosti, vytvořená pomocí metody $\mathrm{ABC}$. V důsledku vzájemného propojení aktivit mohou nastat kolizní stavy a odpovědný pracovník nebo odpovědný kolektiv často není schopen zaručit splnění stanovených kritérií výkonnosti.

- Systém je citlivý na vnitřní a vnější vlivy (poruchy, nedodání materiálu, prŕrodní pohromy). Ve svém důsledku není schopen kontinuálně změny zachytit a reagovat na ně. Náklady se pak skokem zvyšují, což ovlivní zejména ekonomiku firmy.

\section{Návrhy na odstranění nedostatků metody $\mathrm{ABC}$ a řízení výkonnosti}

Zavedení samotné metody BSC nedostačuje pro kvalitní řízení. Žádná ze čtyř perspektiv se neobejde bez jednoho ze spojujících článkủ a tím je řízení nákladů. Nelze řídit oblasti financí, interních procesů a lidských zdrojů bez analýzy procesů, nákladovosti, měřítek a ukazatelů výkonnosti. Proto je bezpodmínečně nutné doplnit strategickou metodu BSC o metodu řízení nákladů, což metoda $\mathrm{ABC}$ splňuje. Použití metody $\mathrm{ABC}$ poskytne nákladový přehled jednotlivých oblastí BSC a navíc umožní vytvoření výkonnostních kritérií pro jednotlivé aktivity. $Z$ kritických bodů implementace a z nedostatků samotné metody $\mathrm{ABC}$, uvedených v předešlém bodě vyplývá, že je nutné, aby byla provedena revize jednotlivých procesů, aktivit a činností. Bez této revize není možné přesné nastavení parametrů použitých v metodě ABC. Metoda, která usnadní kontinuální reengineering procesů, se nazývá Business Process Management (BPM). Jde o procesně orientovaný př́stup, charakterizovaný nutností popisu, analýzy a optimalizace (zlepšování) podnikových procesů, který je založen na potřebách a přáních zákazníků.

Hlavními strůjci a vykonavateli jednotlivých procesů jsou zaměstnanci. Pro komplexnější ř́zení nákladů a výkonnosti je tedy nutné doplnit uvedené metody ještě o další manažerskou metodu řízení výkonnosti, a tou je Performance Management (PM), tedy řízení pracovního 
výkonu. Správné nastavení a samotné řízení pracovního výkonu pomáhá nejen motivovat pracovníky, ale zajistí také předpokládanou výkonnost se zdroji, které jsou ve firmě k dispozici. Nesmí se rovněž zapomínat ani na zpětnou vazbu, tedy hodnocení pracovního výkonu. Lidské zdroje jsou ve firmě nejhodnotnější, ale také nejrizikovější prvek ovlivňující výkonnost firmy. Řízení pracovního výkonu je tedy dalším důležitým prvkem v manažerském řízení, avšak bez spojení s metodami BSC, BPM a ABC není dosaženo synergického efektu. Aby firma vykazovala mnohem větší stabilitu a zvyšovala svou výkonnost, musí být zavedení všech uvedených metod $\mathrm{v}$ jejich vzájemném propojení.

Protože z uvedených nedostatků metody $\mathrm{ABC}$ vyplynulo také nebezpečí vlivu možných vnitřních a vnějších vlivů, které mohou nečekaně ovlivnit optimální průběh procesu (a tím nepředvídatelně navýšit náklady), je nutné tato rizika do maximální míry eliminovat jejich předvídáním a zabezpečením. K tomu se nejlépe hodí manažerská metoda Business Continuity Management (BCM).

Každá vyspělá firma má jako jeden ze svých cílů dlouhodobě působit na trhu a získávat větší tržní podíl. Dlouhodobý horizont udržitelnosti firmy je základním principem metody BCM, která zahrnuje všechny budoucí aspekty, které by mohly společnost zevnitř nebo zvenčí ovlivnit. Vrcholový manažer musí postupovat podobně jako šachista, který přemýšlí nad několika tahy dopředu. Stejně tak je nutné pracovat i s metodou BCM. Jak management, tak i zaměstnanci musí zohledňovat všechny možné varianty, které by procesy ve firmě mohly destabilizovat.

Propojení a vzájemné souvislosti pěti základních manažerských metod je na obrázku 5. Tento př́stup se připravuje $\mathrm{k}$ aplikaci v uvedené výrobní firmě s předpokládanou realizací v roce 2016.

Obrázek 5: Vzájemné propojení 5 základních manažerských metod

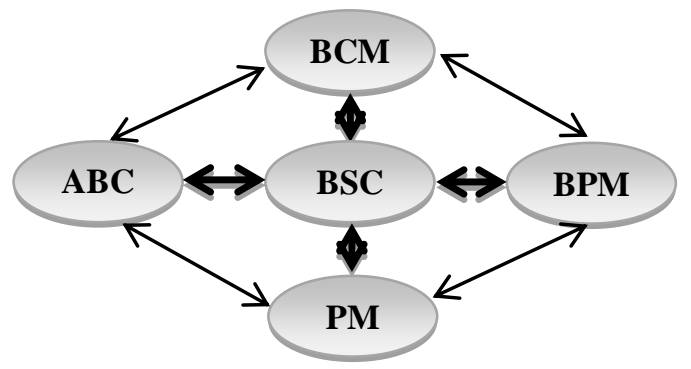

Zdroj: vlastní zpracování

\section{Závěr}

$\mathrm{Na}$ př́padové studii implementace metody řízení nákladů $\mathrm{ABC}$ ve výrobní firmě byly ukázány možnosti využití této metody i s praktickými ukázkami vyhodnocení výsledkủ. Konkrétní výsledky analyzovaly stěžejní aktivity s hodnotou režijního nákladového zatížení. Pro strategické rozhodování posloužil rozbor nákladových objekti̊ (produktových řad) s mírou jejich ziskovosti. To vše v návaznosti na stanovení měřítek a ukazatelů výkonnosti pro strategické plánování pomocí metody BSC. V další části příspěvku byly specifikovány problémy a nedostatky samotné metody $\mathrm{ABC}$. Implementace ukázala, že tato metoda je sice vhodným nástrojem pro identifikaci zdrojů nákladů, ale v rámci samotného řízení už není tak účinná. Navržený komplexní manažerský systém by měl tyto zjištěné nedostatky eliminovat a zajistit kvalitnější řízení jak nákladů, tak i výkonnosti. Všechny cíle příspěvku byly splněny. 


\section{Literatura}

[1] AMSP, 2011. Výsledky průzkumu č. 10 AMSP ČR - Názory podnikatelů na moderní metody ř́zeni společnosti [online]. [vid. květen 2011]. Dostupné z: www.amsp.cz/uploads/dokumenty/AMSP_Pruzkum_C10.pdf

[2] DOYLE, D. P, 2006. Strategické ř́zení nákladi̊: Cost control, a strategic guide. Praha: ASPI. ISBN 80-7357-189-7.

[3] JAMES, W. a A. ELMEZUGHI, 2010. The combined effect of costing and performance management systems on performance, moderated by strategy: Australian context. Accounting, Accountability \& Performance, 16(1/2), 51. ISSN 1445-954X.

[4] JOHNSON, C. C., 2007. Introduction to the balanced scorecard and performance measurement systems. In: Balanced Scorecard for State-Owned Enterprises: Driving Performance and Corporate Governance [online]. ADB. Dostupné z: www.thepresidency.gov.za/electronicreport/downloads/volume_4/business_case_viabilit y/BC1_Research_Material/Balanced_Scorecard_for_SOEs.pdf

[5] KAPLAN, R. S. a D. P. NORTON, 2007. Balanced scorecard: strategický systém měrení výkonnosti podniku. Praha: Management Press. ISBN 978-80-7261-177-5.

[6] KAPLAN, R. S. a D. P. NORTON, 2010. Efektivní systém ř́zení strategie: nový nástroj zvyšování výkonnosti a vytvářeni konkurenčni výhody. Praha: Management Press. ISBN 978-80-7261-203-1.

[7] KRÁL, B., 2010. Manažerské účetnictví. Praha: Management Press. ISBN 978-80-7261217-8.

[8] MAIGA, A. S. a F. A. JACOBS, 2003. Balanced Scorecard, Activity-Based Costing And Company Performance: An Empirical Analysis. Journal of Managerial Issues, 15(3), 283-301. ISSN 1045-3695.

[9] PETŘÍK, T., 2007. Procesní a hodnotové rízení firem a organizací - nákladová technika a komplexní manažerská metoda: ABC/ABM (Activity-based costing/Activity-based management). Praha: Linde. ISBN 978-80-7201-648-8.

[10] POPESKO, B., 2009. Moderní metody ř́zení nákladi̊: jak dosáhnout efektivního vynakládání nákladi̊ a jejich snížení. Praha: Grada. ISBN 978-80-247-2974-9.

[11] WU, S. a J. CHEN, 2012. The performance evaluation and comparison based on enterprises passed or not passed with ISO accreditation: An appliance of BSC and ABC methods. International Journal of Quality \& Reliability Management, 29(3), 295-319. ISSN 0265-671X. 